Original Paper

\title{
Hydrogen Production from Japanese Cedar by the Low-temperature Catalytic Gasification
}

\author{
Kenji MuraKami, Takahiro Kato, and Katsuyasu SugawarA \\ (Received October 10, 2012)
}

スギの低温触媒ガス化による水素製造

村上賢治，加藤貴宏，菅原勝康

\begin{abstract}
The influence of nickel catalyst on the tar evolution in the pyrolysis and the amount of hydrogen evolution in the steam gasification of Japanese cedar (hereafter referred to as Sugi) below $500{ }^{\circ} \mathrm{C}$ was examined in this study. The pyrolysis of Sugi without nickel catalyst produced 22.6 and 20.6 wt.\% (dry ash free, daf) of char at 450 and $500{ }^{\circ} \mathrm{C}$, respectively. The char yield increased gradually with increasing the amount of nickel catalyst and reached 32.0 and 27.6 wt.\% (daf) at 450 and $500{ }^{\circ} \mathrm{C}$ for the Sugi with $8.3 \mathrm{wt. \%}$ of nickel, respectively. The XRD showed that the nickel catalyst in the pyrolyzed char existed as a metallic state for all nickel-loaded samples and the crystallite size was very small. The steam gasification of Sugi without nickel catalyst did not occur below $500{ }^{\circ} \mathrm{C}$. On the other hand, the char conversion for the Sugi with nickel catalyst drastically increased more than 95 wt.\% (daf) at $500{ }^{\circ} \mathrm{C}$. And the amount of hydrogen evolution reached 130-140 mmol/g-Char (daf) for all samples, which corresponded to the amount calculated from the carbon content in the pyrolyzed char.
\end{abstract}

\section{Key Words}

Biomass, Steam gasification, Nickel catalyst, Hydrogen production

\section{1. 緒 言}

木質などのバイオマスはカーボンニュートラルであるため, 地球温暖化問題の解決のための将来のエネルギー源及び化学 原料源として期待されている。現在，未利用木質資源（例え ば，廃木材や間伐材など）の利用法として，直接燃焼による 発電1) 2) や，ガス化・液化・熱分解などの熱化学的変換3) -13), メ夕ン発酵・エ夕ノール発酵などの生物化学的変換 ${ }^{14)}$ 15) など が考えられている。中でも水蒸気ガス化は，クリーンな燃料 である水素を製造することができるため非常に魅力的である。 しかしながら，ガス化反応は通常 $800{ }^{\circ} \mathrm{C}$ 以上の高温を必要と しているため，エネルギー効率の観点から，できるだけ低温 でガス化できる方が好ましい。また，バイオマスは石炭と比 較して酸素含有量が多いので，ガス化時には一般に酸化され たタールを放出する。このタールはあまり利用価值がなく，し かもガス化炉内に残留して反応効率の低下を招くため，除去 又は低減しなければならない。

我々はこれまで石炭の一種である褐炭の熱分解に及ぼす金

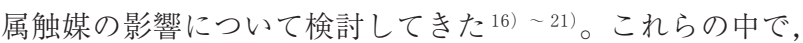

Department of Engineering in Applied Chemistry,

Faculty of Engineering and Resource Science, Akita University

1-1, Tegata Gakuen-machi, Akita shi, Akita 010-8502, Japan
我々はニッケルや鉄，カルシウムなどの金属触媒はタールの 低分子化を促進し，ガス収率を増加させること，及びその効 果は担持量に依存することを報告した。これは熱分解などで 生成した不安定なラジカルが再結合してより大きな分子にな る前に触媒上で分解させられるからと考えている。更に，物 理混合法よりも含浸法やイオン交換法などによる直接担持法 の方が反応性は高いことも明らかにした。これは含浸法やイ オン交換法で担持された触媒の方が分散度は高いためである。 このように褐炭表面上に金属触媒を直接担持して熱分解する と揮発性成分の組成が変化することが分かった。しかしなが

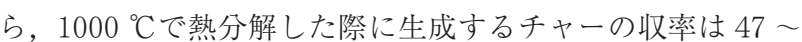
48 wt.\%（dry ash free, daf）で担持金属種や量による違いは ほとんど見られなかった。一方，我々の過去の研究 22 による と，スギを $1000{ }^{\circ} \mathrm{C}$ ま゙熱分解した場合のチャー収率は，無触 媒時の 18.8 wt.\%（daf）から 7.2 wt.\%（dry）の鉄を担持した スギの場合の $34.8 \mathrm{wt}$ \% （daf）まで大きく増加した。これは タール収率が無触媒時の $32.0 \mathrm{wt} \%$ （daf）から $7.2 \mathrm{wt}$ \% 鉄担 持スギの 2.9 wt.\%（daf）まで大きく減少したこと，ならびに

秋田大学大学院工学資源学研究科 環境応用化学専攻 干 010-8502 秋田県秋田市手形学園町 1-1 
$\mathrm{CO}$ 及び $\mathrm{CO}_{2}$ 生成量の顕著な増加と関連している。つまり，ス ギ表面上に存在している鉄触媒はタールを二次分解してCO及 び $\mathrm{CO}_{2}$ を放出すると共にチャー中に炭素を取り込むという役 割を果たしている。この結果はガス化に利用可能なチャー中 炭素量を増加させるという点で非常に興味深い。また, 以前, 我々は稲わらにニッケルを含浸担持し, 室温から $900{ }^{\circ} \mathrm{C}$ まで 昇温しながら水蒸気ガス化を行い, ニッケル触媒が水素生成 量や水素生成温度にどのような影響を与えるか検討した $\left.{ }^{23)} 24\right) 。$ そこでは，1 wt.\%程度の少量のニッケル担持量で水素生成量 が大きく増加すること, 及びニッケル担持量の増加に伴い水 素生成速度が最大になる温度が無触媒時の $900{ }^{\circ} \mathrm{C}$ から $700{ }^{\circ} \mathrm{C}$ へとシフトすることが示された。このようにニッケル触媒は 水蒸気ガス化において, ガス化温度の低温化, チャー中に取 り込まれる炭素量の増加, 及び水素生成量の増加などに効果 があると期待される。そこで本研究では，1１0 wt.\%のニッ ケルをスギに含浸法で担持して $500{ }^{\circ} \mathrm{C}$ 以下の低温で水蒸気ガ ス化し，チャー転化率や水素生成に及ぼすニッケル触媒の影 響を検討することを目的とした。

\section{2. 実験方法}

\section{1 試 料}

試料としてスギ (Japanese Cedar, Cryptomeria japonica D.Don）木質部を $250 \mu \mathrm{m}$ 以下に粉砕したものを使用した。試 料中の炭素, 水素, 及び窒素量を元素分析装置 (Yanaco HCN corder MT-700HCN）を用いて測定した結果，C：46.8 wt.\% (dry), H: 5.8 wt.\% (dry), N : 0.1 wt.\% (dry), O (diff.) : 47.0 wt.\%(dry) であった。また, JIS M 8812 (石炭類及びコーク 又類一工業分析方法）に従い工業分析值を測定した結果，水 分: 6.8 wt.\% (dry), 揮発分: 77.8 wt.\% (dry), 灰分 : 0.3 wt. \% (dry), 固定炭素：15.1 wt.\% (diff.)であった。

\section{2 含浸法によるニッケル塩担持}

試料 $10 \mathrm{~g}$ に対し $1 ， 5 ， 10 \mathrm{wt}$ \% のニッケル担持量になる ように $\mathrm{Ni}\left(\mathrm{NO}_{3}\right)_{2} \cdot 6 \mathrm{H}_{2} \mathrm{O}$ を含む水溶液 $200 \mathrm{ml}$ を加えた。その後,

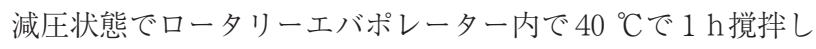

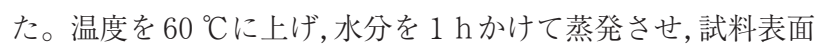
上にニッケル塩を析出させた。ニッケル担持木質試料は $110{ }^{\circ} \mathrm{C}$ で $12 \mathrm{~h}$ 乾燥した。乾燥後, 試料を $815{ }^{\circ} \mathrm{Cで}$ 灰化し, 残った灰 分がNiOであると仮定し，実際のニッケル担持量を決定した。 このようにして決定された試料中のニッケル担持量は 0.92 , 4.4, 8.3 wt.\% (dry) であった。以降, 試料名は $\mathrm{Ni} の$ 担持量 （wt.\%）で表すことにする。

\section{3 水蒸気ガス化}

水蒸気ガス化は Fig. 1 に示す固定床反応装置を用いて行わ れた。試料 $0.5 \mathrm{~g}$ をアルミナボートに載せ, 水平型固定床反応 器内に設置し, $\operatorname{Ar}$ 気流 $(60 \mathrm{ml}-\mathrm{NTP} / \mathrm{min})$ 中で室温から $100{ }^{\circ} \mathrm{C} /$ min で所定の温度 $\left(450\right.$ または $\left.500{ }^{\circ} \mathrm{C}\right)$ まで昇温し, $10 \mathrm{~min}$ 保 持することで熱分解チャーを作製した。その後，50 vol.\%水蒸 気/ $\mathrm{Ar}$ (トータル流量: $120 \mathrm{ml}-\mathrm{NTP} / \mathrm{min}$ )に切り替え， 450 ま たは $500{ }^{\circ} \mathrm{C} て ゙ 1 \mathrm{~h}$ ガス化を行った。 $5 \mathrm{~min}$ 毎に生成ガスをサ ンプリングし, GC (検出器：TCD）を用いて, $\mathrm{H}_{2}, \mathrm{CH}_{4}, \mathrm{CO}$, 及び $\mathrm{CO}_{2}$ を定量した。ガス化転化率は熱分解チャー収率とガ ス化後の重量から算出された。

\section{4 ニッケル触媒の形態や結晶子径の評価}

熱分解およびガス化後のチャー中のニッケル触媒の結晶形 態と分散状態を調べるためにXRD (Rigaku Ultima IV) 測定を 行った。測定条件は発散スリット $2 / 3^{\circ}$ ，受光スリット $0.3 \mathrm{~mm}$, 走査範囲 $2 \theta=10.000 \sim 90.000^{\circ}$ ，スキャンスピード $10.000^{\circ}$ / min，サンプリング幅 $0.2^{\circ}$ に設定し， CuK $\alpha$ 線を用いて測定を 行った。得られたデータから以下の Scherrerの式を用いて熱 分解および水蒸気ガス化後の残渣中のニッケル触媒の結晶子 径を算出した。

$$
L=\frac{K \lambda}{\beta \cos \theta}
$$

ここで，Lは結晶子径 $(\AA) ， \lambda$ はX線の波長で $1.5418 \AA ， \beta$ は回折線の半值幅 $(\mathrm{rad}), \theta$ は回折角 $\left(^{\circ}\right), K$ は定数で 0.9 と した。

\section{3. 結果と考察}

3.1 熱分解に及ぼすニッケル触媒の影響

Fig. 2 に 450 および $500{ }^{\circ} \mathrm{C}$ で熱分解後のチャー収率とニッ ケル担持量の関係を示す。チャー収率 $Y_{\text {Char }}[\mathrm{wt} . \%$, daf]は式 (2)を用いて算出した。

$$
Y_{\text {Char }}=\frac{W_{\text {Char }}}{W_{\text {Sugi }}} \times 100
$$

ここで，W $W_{\text {Char }}[\mathrm{g}, \mathrm{daf}]$ は熱分解後のチャー重量，W Sugi $[\mathrm{g}, \mathrm{daf}]$ は仕込みのスギ重量である。無触媒の場合, 以前の熱重量分 析の結果から，揮発分の放出は $250 \sim 380{ }^{\circ} \mathrm{C} て ゙$ 起こることが

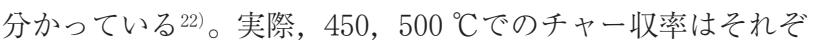

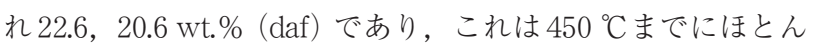

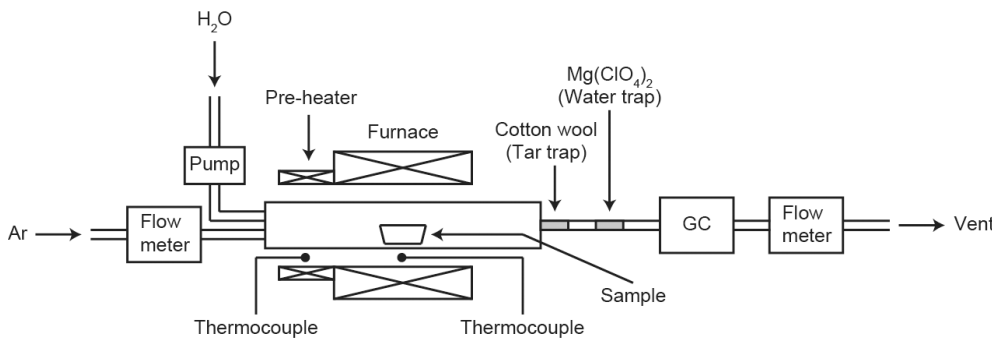

Fig. 1 Schematic illustration of experimental apparatus 
どの揮発分が放出されたことを示している。Fig. 2 からニッ ケル担持量を増加させると，いずれの温度でもチャー収率は 単調に増加していることは明らかであり， $8.3 \% \mathrm{Ni}$ では 450, 500 ㅇでチャー収率はそれぞれ 32.0，27.6 wt.\%（daf）となっ た。熱分解チャーの元素分析值をTable 1に示す。窒素の值が ニッケル担持量の増加に伴い増加しているが，これは熱分解 後も硝酸痕が残存しているためと考えられる。Fig. 2のチャー 収率と Table 1の炭素含有量の積はチャー中に残存している炭 素量を意味する。式(3)に示すように，この炭素量を元々の Sugi中の炭素量 $C_{\text {sugi }}=46.9$ wt.\% (daf) で割れば，元々のSugi 中の炭素のうち，チャー中に残存した炭素の割合 $X_{C}[\mathrm{~mol} \%]$ を 計算することができる。

$$
X_{C}=\frac{W_{\text {Char }} \times C_{\text {Char }}}{W_{\text {Sugi }} \times C_{\text {Sugi }}} \times 100=\frac{Y_{\text {Char }} \times C_{\text {Char }}}{C_{\text {Sugi }}} \times 100
$$

ここで, $C_{\text {char }}[w t . \%$, daf]は Table 1 のチャー中の炭素量であ る。Table 1に各条件におけるXCの值も示す。Sugi 試料では, 450 及び 500 ㄷでの熱分解後に炭素は 37.5 及び $36.7 \mathrm{~mol} \%$ し かチャーに残存しない。即ち, 残りの約 $63 \mathrm{~mol} \%$ は $\mathrm{CO}^{\circ} \mathrm{CO}_{2}$, タールとして気相中に放出される。このチャー中残存炭素の 割合はニッケル担持量の増加に伴い単調に増加し, $8.3 \% \mathrm{Ni}$ 担 持スギ試料では約 $50 \mathrm{~mol} \%$ も炭素がチャー中に残存するこ

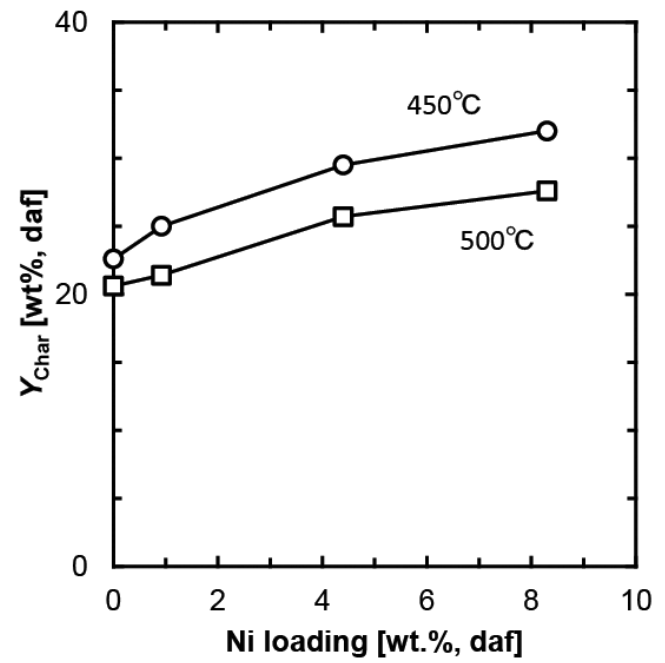

Fig. 2 Effect of nickel loading on char yield in pyrolysis
とが明らかとなった。これはニッケルが揮発分の 2 次分解を 促進し, 一部は気体として放出され, 残りはチャー中に炭素 として取り込まれているためである。このようにニッケルを スギ上に直接担持することで，その後のガス化に利用可能な 炭素量が増加することが明らかとなった。

Fig. 3 に熱分解後のチャーの XRD パターンの一例を示す。 $8.3 \% \mathrm{Ni}$ 試料を $500{ }^{\circ} \mathrm{C}$ で熱分解した後のチャーではっきりと観 察することができるが， 3 本の回折線 $\left(2 \theta=44.51^{\circ} ， 51.85^{\circ}\right.$, 及び76.37 ) が現れた。これらは低角側から $\mathrm{Ni}(111), \mathrm{Ni}(200)$, 及び $\mathrm{Ni}(220)$ に爱属された。 $0.92 \% \mathrm{Ni}$ 試料を $450{ }^{\circ} \mathrm{C}$ で熱分解 したチャーでもかなり強度は小さいが，金属ニッケルに帰属 される回折線 $\left(44.51,51.85^{\circ}\right)$ が現れており，ニッケル触媒 は本実験条件ではいずれの場合でもガス化時には既に金属 ニッケルへと還元された状態でチャー表面上に存在している ことが明らかとなった。最も金属ニッケルの結晶子径が大き いと考えられる $8.3 \% \mathrm{Ni}$ 試料を $500{ }^{\circ} \mathrm{C}$ で熱分解した場合の金属 ニッケルの結晶子径を式(1) を用いて算出した結果，約 $7 \mathrm{~nm}$ と非常に小さいことが分かった。一方，炭素については関連 する回折線が見られなかったことより無定形の状態で存在し ていることが分かった。

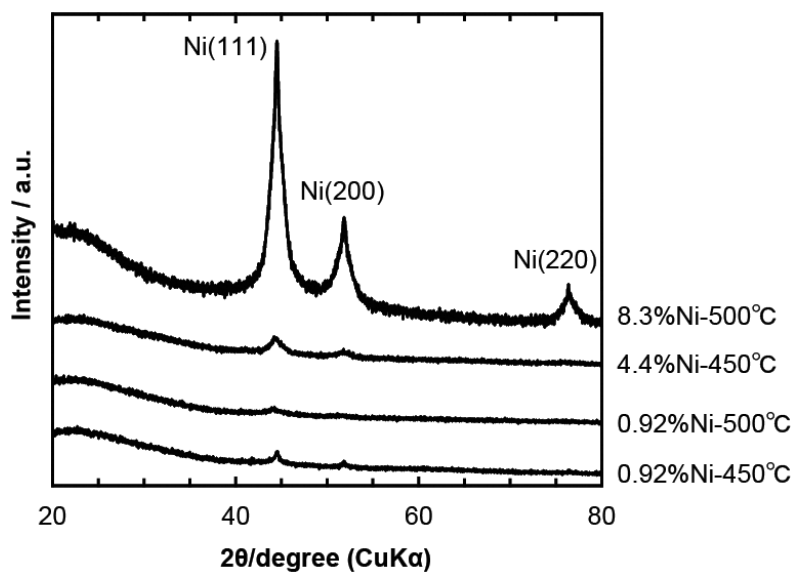

Fig. 3 XRD patterns of pyrolyzed chars

Table 1 Elemental analyses of pyrolyzed chars

\begin{tabular}{|c|c|c|c|c|c|}
\hline & \multicolumn{4}{|c|}{ Elemental analysis [wt.\%, daf] } & \multirow{2}{*}{$X_{C}[\mathrm{~mol} \%]$} \\
\hline & $\mathrm{C}$ & $\mathrm{H}$ & $\mathrm{N}$ & $\mathrm{O}$ (diff.) & \\
\hline \multicolumn{6}{|l|}{$450{ }^{\circ} \mathrm{C}$} \\
\hline Sugi & 77.9 & 2.9 & 0.6 & 18.6 & 37.5 \\
\hline $0.92 \% \mathrm{Ni}$ & 78.5 & 3.1 & 1.1 & 17.3 & 41.8 \\
\hline $4.4 \% \mathrm{Ni}$ & 75.2 & 2.9 & 2.3 & 19.6 & 47.3 \\
\hline $8.3 \% \mathrm{Ni}$ & 75.9 & 2.9 & 3.2 & 18.0 & 51.8 \\
\hline \multicolumn{6}{|l|}{$500{ }^{\circ} \mathrm{C}$} \\
\hline Sugi & 83.6 & 2.4 & 0.6 & 13.4 & 36.7 \\
\hline $0.92 \% \mathrm{Ni}$ & 81.2 & 3.0 & 1.1 & 14.7 & 37.1 \\
\hline $4.4 \% \mathrm{Ni}$ & 80.3 & 2.6 & 2.2 & 14.9 & 44.0 \\
\hline $8.3 \% \mathrm{Ni}$ & 81.4 & 2.7 & 3.0 & 12.9 & 47.9 \\
\hline
\end{tabular}


3.2 水蒸気ガス化時のチャー転化率, 反応速度, ニッケル 触媒の形態

Fig. 4 に 450 および $500{ }^{\circ} \mathrm{C}$ で水蒸気ガス化後のチャー転化 率を示す。なお，チャー転化率X $X_{\text {Char }}[w t . \%$, daf]は式(4)を用 いて算出された。

$$
X_{\text {Char }}=100-\frac{W_{\text {Residue }}}{W_{\text {Sugi }} \times \frac{Y_{\text {Char }}}{100}} \times 100=100-\frac{W_{\text {Residue }}}{W_{\text {Char }}} \times 100
$$

ここで，WResidue $[\mathrm{g}$, daf]はガス化後の残渣重量である。Sugi試 料の場合，500 ${ }^{\circ} \mathrm{C}$ 以下ではチャー転化率は 5 wt.\% (daf) 以下 でほとんどガス化しなかった。一方，ニッケル担持試料の場 合，チャー転化率は大きく増加し， $450{ }^{\circ} \mathrm{C}$ では 60 ～ 80 wt.\% (daf)となった。 $500{ }^{\circ} \mathrm{C}$ では更に転化率が増加し，0.92 wt.\%と いう少量のニッケル担持量でも，チャー転化率は 95 wt.\% (daf)に達した。このようにニッケル触媒を $1 \mathrm{wt}$ \% 程度担持 することにより $500{ }^{\circ} \mathrm{C} ， 1$ 時間の反応でスギを完全にガス化す

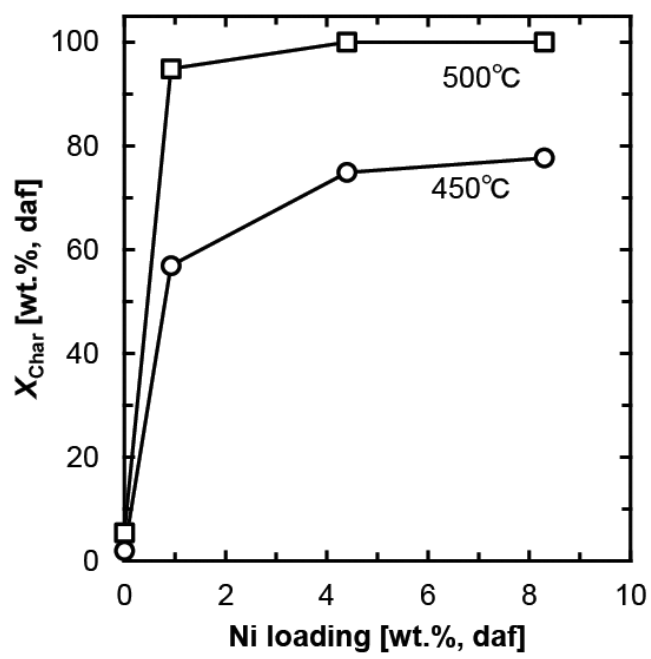

Fig. 4 Effect of nickel loading on char conversion in steam gasification

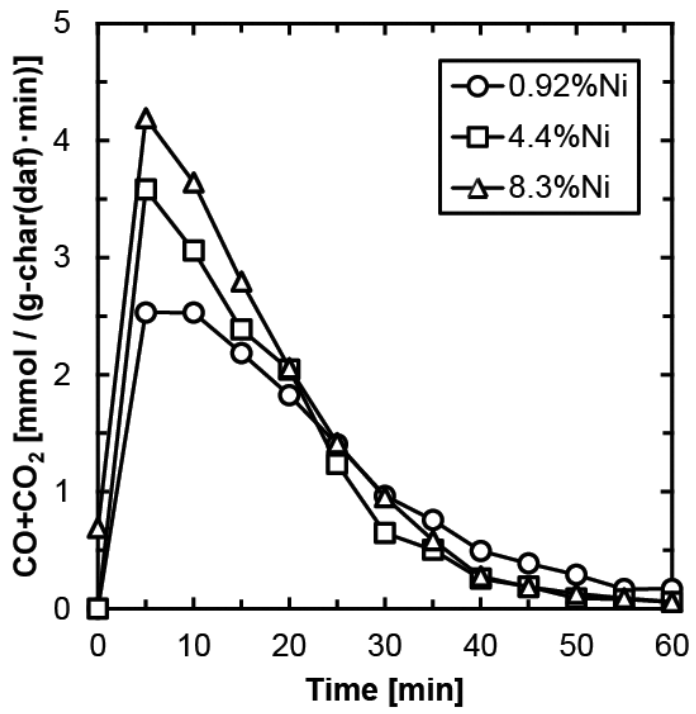

Fig. $5 \mathrm{CO}$ and $\mathrm{CO}_{2}$ evolution profiles during steam gasification of nickel-impregnated Sugi samples at $500{ }^{\circ} \mathrm{C}$
ることができた。

Fig. 5 に $500{ }^{\circ} \mathrm{C}$ で水蒸気ガス化した際の $\mathrm{CO}$ と $\mathrm{CO}_{2}$ の生成速 度の和の経時変化を示す。この温度では $\mathrm{CH}_{4}$ は全く生成しな かったので, Fig. 5 には $\mathrm{CO}$ と $\mathrm{CO}_{2}$ の和のみを示した。また, $\mathrm{CO}$ 生成量も $\mathrm{CO}_{2}$ 生成量と比較するとごく僅かであった。例え ば， $8.3 \% \mathrm{Ni}$ 試料を $500{ }^{\circ} \mathrm{C} て ゙ 1 \mathrm{~h}$ ガス化した際に生成した CO/ $\mathrm{CO}_{2}$ モル比は0.06に過ぎなかった。Fig. 5 から，全ての試料に おいて反応開始 5 min後に最大生成速度に達し，それ以降，生 成速度は減少したことが分かった。また，ニッケル担持量を 増加させると, $\mathrm{CO}+\mathrm{CO}_{2}$ 最大生成速度も増加した。この $\mathrm{CO}$ と $\mathrm{CO}_{2}$ 生成速度を数值積分すると, $\mathrm{CO}$ と $\mathrm{CO}_{2}$ の生成量が得ら れ，更にチャーに含まれる炭素量 $C_{\text {Char }}$ で割ると，炭素転化率 $X_{\mathrm{Char}, \mathrm{C}}[\mathrm{mol} \%]$ を計算することができる。ここで，触媒性能を 評価するために，500 ${ }^{\circ} \mathrm{C}$ で水蒸気ガス化した際の炭素転化率と ガス化比速度の関係を検討した（Fig. 6)。なお，比速度 $R[1$ ) h]は式(5)を用いて計算した。

$$
R=\frac{R_{\mathrm{C}}}{1-\frac{X_{\text {Char, }}}{100}}
$$

ここで，Rc $[\mathrm{mol} \% / \mathrm{h}]$ は $\mathrm{CO}$ と $\mathrm{CO}_{2}$ の生成速度の和をチャーに 含まれる炭素量 $C_{\text {char }}$ で割って求められる炭素転化速度である。 ただし，式(5)の分母はチャー中に残存している炭素の割合と した。Fig. 6から炭素転化率が高くなると比速度が増加するこ とが分かる。これはニッケルの触媒活性は反応が進行しても ほとんど低下しないためと考えられる。また，残存炭素量に 対してニッケル担持量が相対的に高くなることも一因である と考えられる。この図からはニッケル担持量を増加させると, 比速度が単調に増加することも分かった。

水蒸気ガス化温度が 450 及び $500{ }^{\circ} \mathrm{C}$ の場合の炭素収支を Fig. 7に示す。なお, 図中のチャーは水蒸気ガス化後の残渣が 全て炭素であると仮定して計算した。無触媒の場合，いずれ の温度でも炭素はほとんどがチャーとして残存した。一方，

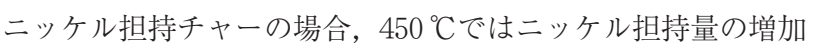

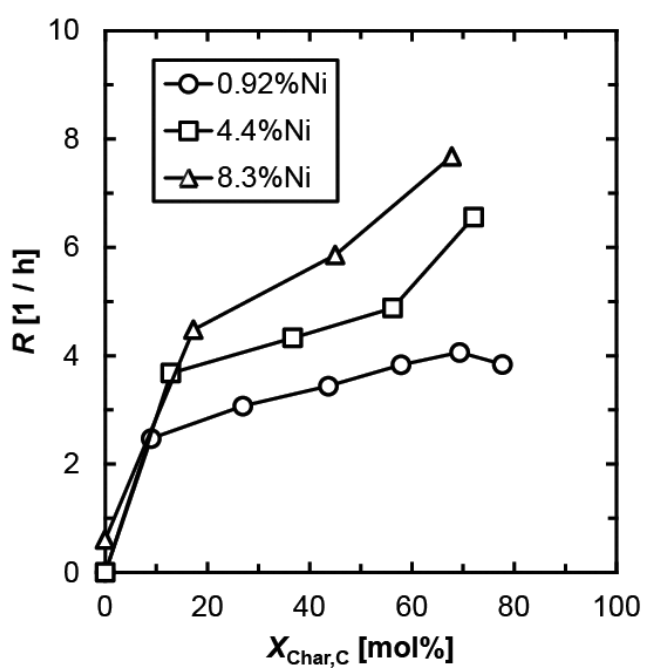

Fig. 6 Relation between carbon conversion and specific rate in steam gasification of nickel-impregnated Sugi samples at $500{ }^{\circ} \mathrm{C}$ 
(a) $450^{\circ} \mathrm{C}$

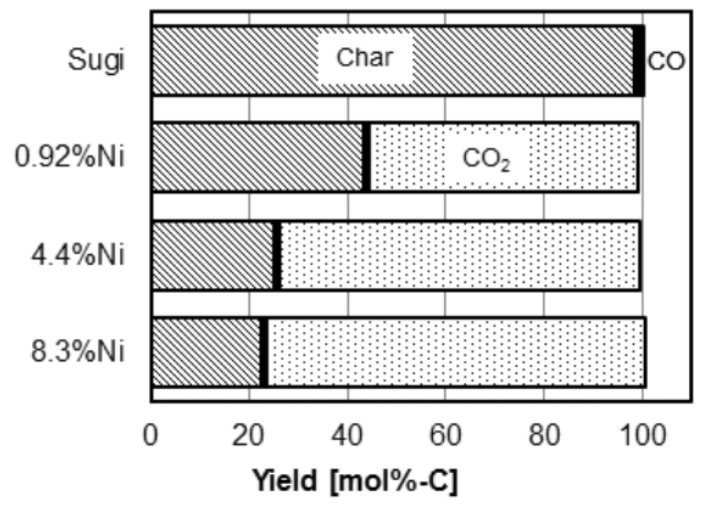

(b) $500^{\circ} \mathrm{C}$

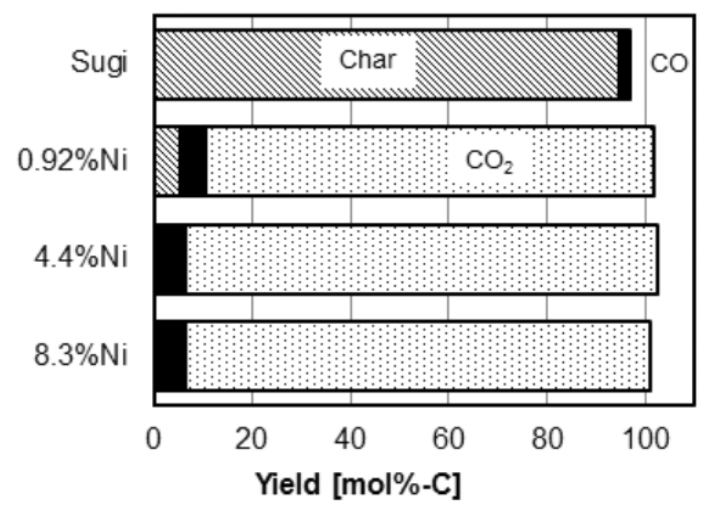

Fig. 7 Carbon balance in steam gasification of nickel-loaded Sugi samples at (a) $450{ }^{\circ} \mathrm{C}$ and (b) $500^{\circ} \mathrm{C}$

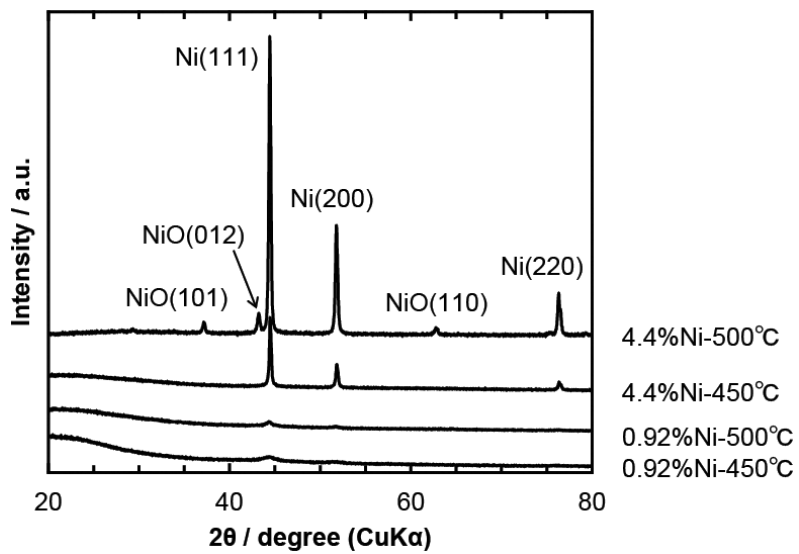

Fig. 8 XRD patterns of residues after steam gasification

に伴い，チャー収率の減少及び $\mathrm{CO}_{2}$ 生成量の増加が認められ

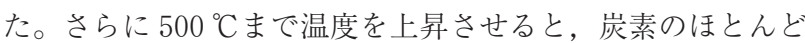
は $\mathrm{CO}_{2}$ として放出された。

Fig. 8 に種々の条件で水蒸気ガス化した際の残渣の XRD パ ターンを示す。いずれの場合もニッケルは，金属ニッケルと して存在していた。一方， $4.4 \% \mathrm{Ni} 500{ }^{\circ} \mathrm{C}$ で水蒸気ガス化し た場合は金属ニッケルの他に酸化ニッケルの回折線も現れた。 これはXRD測定時に空気中に試料が曝された結果，空気中の 水蒸気と反応してしまい酸化してしまったものと考えられる。

\section{3 水蒸気ガス化による水素生成}

Fig. 9 に $500{ }^{\circ} \mathrm{C}$ で水蒸気ガス化した際に放出された水素の生 成速度の経時変化を示す。 $\mathrm{CO}+\mathrm{CO}_{2}$ 生成速度と同様に反応時 間 $5 \mathrm{~min}$ 後に最大生成速度に達し, その後, 生成速度は減少 した。最大水素生成速度は $0.92 \% \mathrm{Ni}$ の $5.2 \mathrm{mmol} /(\mathrm{g}-\mathrm{Char} ・ \mathrm{~min})$ に対し，4.4\% Niでは $7.1 \mathrm{mmol} /$ (g-Char・min) と約 1.4 倍に増 加した。しかしながら，ニッケル担持量をそれ以上増加させ ても水素最大生成速度に違いは認められなかった。この水素 生成速度を数值的に積分して水素生成量を求め, ニッケル担 持量依存性を検討した (Fig. 10)。なお，Fig. 10中の破線は式 （6）に従って，チャー中の全ての炭素がガス化された場合の水 素生成量の計算值 $\left(450,500{ }^{\circ} \mathrm{C}\right.$ では，それぞれ約 130,140 $\mathrm{mmol} / \mathrm{g}$-Char, daf) を示している。

$$
\mathrm{C}+2 \mathrm{H}_{2} \mathrm{O} \rightarrow \mathrm{CO}_{2}+2 \mathrm{H}_{2}
$$

無触媒では Fig. 4 にも示されているように $500{ }^{\circ} \mathrm{C}$ 以下では チャー転化率は 5 wt.\%であり，水素生成量も非常に少なく $3.7 \mathrm{mmol} / \mathrm{g}$-Charであった。一方，ニッケル触媒を担持するこ とにより，水素生成量は著しく増加し， $450{ }^{\circ} \mathrm{C}$ では最大 105 $\mathrm{mmol} / \mathrm{g}$-Char (daf), $500{ }^{\circ} \mathrm{C}$ では約 $140 \mathrm{mmol} / \mathrm{g}$-Char (daf) に 達した。ここで, 理論水素生成量に対する水素生成量の比率

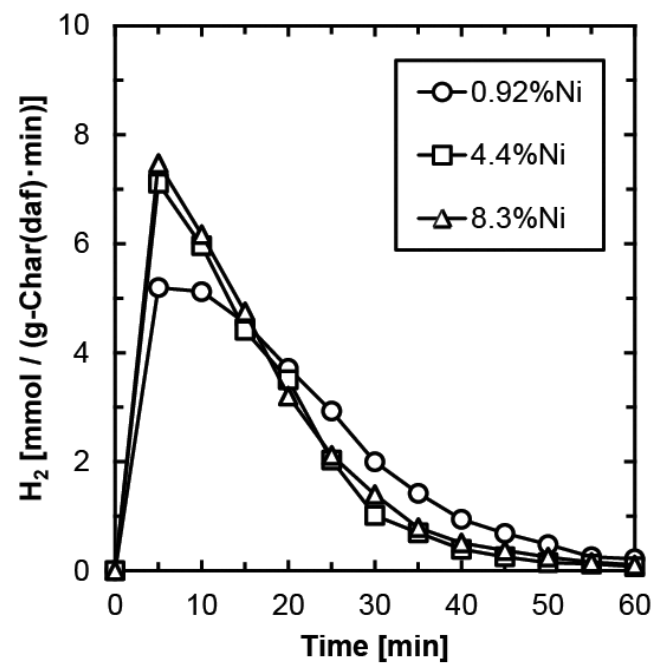

Fig. 9 Hydrogen evolution profiles during steam gasification of nickel-impregnated Sugi samples at $500^{\circ} \mathrm{C}$

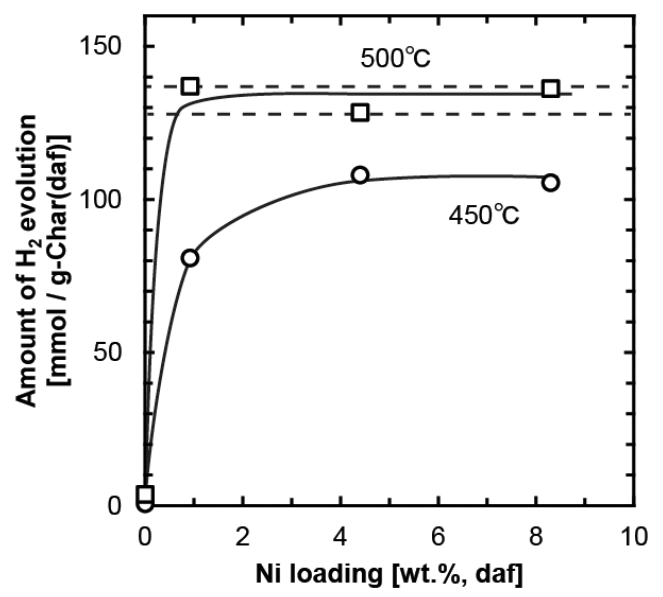

Fig. 10 Effect of nickel loading on amount of hydrogen evolution 


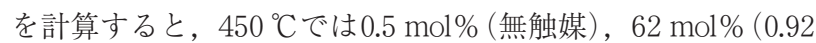
$\% \mathrm{Ni}), 86 \mathrm{~mol} \%(4.4 \% \mathrm{Ni}), 83 \mathrm{~mol} \%(8.3 \% \mathrm{Ni})$ であったのに

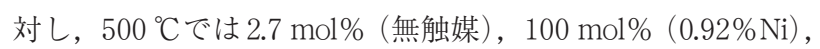
$96 \mathrm{~mol} \%(4.4 \% \mathrm{Ni}), 100 \mathrm{~mol} \%(8.3 \% \mathrm{Ni})$ といずれの場合も 温度上昇に伴い, 水素生成量比率は高くなった。特に $500{ }^{\circ} \mathrm{C}$ では0.92 wt.\%のニッケル担持量で，水素生成量はほぼ理論水 素生成量に達していることが分かる。このことは, Niをスギに 直接担持して水蒸気力゙ス化する場合, 本研究における操作条件 においては $500{ }^{\circ} \mathrm{C}$ という低温でもニッケル担持量は約 1 wt.\% で十分であることを示している。しかしながら，この結果を 実際のプロセスに応用するためにはまだ検討しなければなら ない課題が残っている。例えば, 木質の粒径や固定床の充填 高さなどの操作条件が異なると, ガス化効率は今回の結果と は異なると考えられる。LuO ら 25) や Hernandez ら 26) はガス 化反応に及ぼす木質の粒径の影響を検討しており，粒径が小 さい場合の方がガス収率や炭素転化率が高いことを報告して いる。また，この粒径の影響は低温ほど大きいことも明らか にした。一方, Van de steene ら ${ }^{27)}$ は上流から木質の熱分解 チャーとガス化剤を固定床ガス化炉に連続的に導入して, 層高 に沿った生成ガスの分布を測定しており, 固定床の上層 $10 \mathrm{~cm}$ がガス濃度の変化が最も大きい領域であることを明らかにし た。その領域では, 水蒸気濃度の著しい低下及び水素とCO濃 度の増加が起こり, それより下層では, 水素とCO濃度は徐々 に増加したと報告した。このように操作条件によりガス化効 率は異なるため, 今後, 本研究で得られた結果を最大限に活 かすための操作条件の最適化が必要となる。

\section{4. 結 論}

本研究で得られた結果をまとめると次のようになる。

・ ニッケルを担持することにより, 熱分解時に得られる チャー収率が増加した。また, チャー中の炭素含有量も増 加した。これはニッケルが揮発分の二次分解を促進し, チャー上に炭素を析出させているためである。

・水蒸気ガス化においては, ニッケルを約 $1 \mathrm{wt}$ \% \%担持するこ とにより，500 ${ }^{\circ} \mathrm{C}$ とう低温でもスギの熱分解チャーをほぼ $100 \mathrm{wt} \%$ ガスス化することができた。

· $500{ }^{\circ} \mathrm{C}$ での水素生成量は約 $140 \mathrm{mmol} / \mathrm{g}$ であり, これは チャー中に含まれる炭素がすべてガス化反応に使用された と仮定した計算值と一致した。

\section{文 献: References}

1) Matsumura, Y., Minowa, T., Yamamoto, H., Biomass Bioenergy, 29, $347(2005)$

2) Suramaythangkoor, T., Gheewala, S. H., Appl. Energy., 87, 128
(2010)

3) DeGroot, W., Richards, G., Fuel, 67, 345 (1988)

4) Suzuki, T., Minami, H., Yamada, T., Homma, T., Fuel, 73, 1836 (1994)

5) Suzuki, T., Iwasaki, J., Konno, H., Yamada, T., Fuel, 74, 173 (1995)

6) Blasi, C., Branca, C., Santoro, A., Hernandez, E., Combust. Flame, 124, 165 (2001)

7) Asadullah, M., Miyazawa, T., Ito, S., Kunimori, K., Yamada, M., Tomishige, K., Appl. Catal., 255, 169 (2003)

8) Karagoz, S., Bhaskar, T., Muto, A., Sakata, Y., Fuel, 83, 2293 (2004)

9) Paris, O., Zollfrank, C., Zickler, G., Carbon, 43, 53 (2005)

10) Sagehashi, M., Miyasaka, N., Shishido, H., Sakoda, A., Biores. Technol., 97, $1272(2006)$

11) Hosoya, T., Kawamoto, H., Saka, S., J. Anal. Appl. Pyrolysis, 78, 328(2007)

12) Sutton, D., Kelleher, B., Ross, R. H., Fuel Proc. Technol., 73, 155 (2001)

13) Devi, L., Ptasinski, K. J., Janssen, F. J. J. G., Biomass Bioenergy, 24, $125(2003)$

14) Amirta, R., Tanabe, T., Watanabe, T., Honda, Y., Kuwahara, M., Watanabe, T., J. Biotechnol., 123, 71 (2006)

15) Olsson, L., Hahn-Hagerdal, B., Enzym Microb. Technol., 18, 312 (1996)

16) Murakami, K., Shirato, H., Ozaki, J., Nishiyama, Y., Fuel Proc. Technol., 46, 183(1996)

17) Murakami, K., Shirato, H., Nishiyama, Y., Fuel, 76, 655 (1997)

18) Shirai, M., Murakami, K., Nishiyama, Y., Energy Fuels, 11, 1012 (1997)

19) Shirai, M., Arai, M., Murakami, K., Energy Fuels, 13, 465 (1999)

20) Shirai, M., Arai, M., Murakami, K., Energy Fuels, 14, 1038 (2000)

21) Murakami, K., Arai, M., Shirai, M., Energy Fuels, 16, 752 (2002)

22) Murakami, K., Fuda, K., Sugai, M., J. MMIJ, 124, 143 (2008)

23) Murakami, K., Kasai, K., Kato, T., Sugawara, K., Fuel, 93, 37 (2012)

24) Murakami, K., Sato, M., Kato, T., Sugawara, K., Fuel Proc. Technol., 95, 78(2012)

25) Luo S., Xiao, B., Guo, X., Hu, Z., Liu, S., He, M., Int. J. Hydrogen Energy, 34, 1260 (2009)

26) Hernandez, J.J., Aranda-Almansa, G., Bula, A., Fuel Proc. Technol., 91, 681(2010)

27) Van de steene, L., Tagutchou, J. P., Mermoud, F., Martin, E., Salvador, S., Fuel, 89, 3320(2010) 